

\section{John Wyclif}

\section{MANCHESTER 1824}

Manchester University Press 


\section{John Wyclif}

Selected Latin works in translation

Translated and edited by Stephen Penn

Manchester University Press 
Copyright (C) Stephen Penn 2019

The right of Stephen Penn to be identified as the author of this work has been asserted by him in accordance with the Copyright, Designs and Patents Act 1988.

Published by Manchester University Press

Altrincham Street, Manchester M1 7JA

www.manchesteruniversitypress.co.uk

British Library Cataloguing-in-Publication Data

A catalogue record for this book is available from the British Library

ISBN 9780719067648 hardback

First published 2019

The publisher has no responsibility for the persistence or accuracy of URLs for any external or third-party internet websites referred to in this book, and does not guarantee that any content on such websites is, or will remain, accurate or appropriate.

Cover design: riverdesignbooks.com

Typeset in Monotype Bell by Servis Filmsetting Ltd, Stockport, Cheshire 